\title{
Teaching Effectiveness in Elements of Special Education in NCE- Awarding Institutions in Nigerian:-Influence of Teacher Qualification and Experience
}

\author{
Eleri, N. O.E. \\ Nigerian Educational Research \& Development Council (NERDC), P.M.B. 91, Garki, Abuja, Nigeria
}

\begin{abstract}
Teacher preparation in Nigeria has been changing in response to the emphasis on educating learners with special needs in ways that support their diverse needs. This study attempted to assess teaching effectiveness as it relates to the teaching of Elements of Special Education Curriculum in NCE-awarding Institutions in Nigeria. It also investigated the extent to which teacher qualification and experience influence teaching effectiveness. Descriptive research method of expost facto was employed. The study is also qualitative as it used the observational method to collect data on teaching effectiveness. The population for this study comprised all the 217 lecturers teaching Elements of Special Education Curriculum in these institutions. One instrument was used in this study i.e the Observational Schedule for Classroom Teaching of Elements of Special Education (OCTESE) with inter-rater reliability of 0.82. Data collected were analyzed using descriptive statistics i.e. frequency count, mean and standard deviation as well as one-way analysis of variance [ANOVA] at 0.05 alpha levels. The result revealed that each of the institutions had an average of four experienced lecturers who were academically but not professionally qualified to teach elements of special education. Findings also showed that various aspects of classroom teaching were ineffective (means range from 2.08 to 2.63). Lecturers' qualification and experience did not significantly affect their teaching effectiveness. Towards effective special education teacher preparation in Nigeria, government should employ professionally qualified personnel and put in place a better classroom design and organization towards achievement of the objectives of the curriculum.
\end{abstract}

Keywords: Elements of Special Education, NCE- awarding institutions, Teacher Qualification and Experience, Teaching Effectiveness,

Submitted Date 12 June 2013

Accepted Date: 17 June 2013

\section{Introduction}

The Federal Republic of Nigeria (2004), addresses different sections of Nigerian educational system, including special education. This policy document describes special education as a formal educational training given to people (children and adults) with special needs. It further classifies this group of people into three broad categories namely the disabled, the disadvantaged and the gifted/talented.

Special Education and indeed the care of children and youths with disabilities was handled largely by charitable and humanitarian organisations before 1974. These organisations sometimes received meagre assistance from the government. In 1974, there was direct government involvement in the education and rehabilitation of these groups of people. The Federal Ministry of Education provided the much needed leadership by establishing a special education unit within the Ministry in December, 1974. It also made funds available not only for the training of all categories of special education personnel, but also for the setting up of special education units within the State Ministries of Education (SMoE) to provide educational programmes for special needs children across the country Eleri (2012).

However, there has been a major shift in the way students with special needs are educated during the past 30 or 40 years. Formerly, students with high- incidence disabilities (such as reading disabilities) went unidentified and were educated in general classrooms. General education teachers did not always recognize these disabilities, and even if they did, they might not have had the tools to effectively help the students in the general classroom setting. Students with more profound learning disabilities were typically taught in isolated, self- contained classrooms by a single teacher for the entire day.

Today two important changes have occurred. First, there is now an increased effort to identify and assist students with disabilities while keeping them in general education classrooms for most of their instructional needs. Second, students with more profound disabilities are frequently placed in general education classrooms for all or part of the day, sometimes with a paraprofessional assisting them, and sometimes with a special education teacher advising and assisting the teacher. This change has been brought about by federal 
legislation and by a deeper understanding of how students with special needs learn. Teacher preparation also has been changing in response to the emphasis on educating special- needs students in ways that support their diverse needs - be they educational, emotional, behaviour or cultural (Kavale, 2005; Pugach, 2005).

The introduction of the Universal Primary Education (UPE) in Nigeria in 1976 meant that every child of school going age would be in school. This led to phenomenal increase in enrolment figure in the nation's Primary school system. The awareness created by the introduction of the UPE, therefore, generated the much needed interest in western education. As the nation experienced astronomical increase in enrolment, so also were increase in the number of children with special educational needs in the system. The free Universal Primary Education created a situation whereby children with special needs were admitted into the regular school system. There was population explosion that posed a great challenge to teachers, parents, education authorities and policy makers. This situation gave cause for a re-think on how best to meet the challenges of children with special needs in the regular schools. However, the manpower requirement needed to cope with this new challenge was at this stage lacking.

The pressure of severe shortage of professionals in special needs education and the mainstreaming of special needs learners led to the consideration of the following:

(a) focus on training specialist in special education to teach in special schools even though it may mean a decrease in the required numbers in the mainstream; and

(b) integration of elements of special education into regular teacher education curricula so that every teacher will have some basic knowledge of special needs education to use in the classroom.

The latter option of integrating elements of special education into regular teacher education programme was considered a better option. Addressing the manpower shortage required to cope with the influx of children with special needs into the regular school system by the founding fathers of special education in Nigeria led to the proposal for the establishment of a College of Education (Special) in Oyo, Oyo State.

Aggarwal (1997), states that education is a continuous and lifelong process. It is the process of development from infancy to maturity. It includes the effect of everything which slate and a teacher could write on. Others were of the view that a child was just like clay and a teacher like a potter could make anything out of it. Tania (2004) quoted Sanaullah (2002) who comments that teachers play an important role in fostering environmental consciousness in the society; therefore, more efforts are needed to sharpen the skill of teachers to integrate local environmental content in their teaching methods and activities. Sial (2005) quoting Shah (1995) states that the position of teacher in system of education is important and that no system of education can be better than its teacher. The teacher is the kingpin in the educational setup.

For a long time, there have been arguments about which factors influence the student's achievement. Some researchers attribute the student's achievement to the school; others indicate that the school makes little impact on academic outcome. Numerous studies in recent years have investigated the relationship between various teacher characteristics and the performance of students they teach Harris and Sass (2008). Most studies include general measure of teacher experience and attainment of advanced degrees, but relatively few contain specific measures of pre-service preparation or in-service professional development.

Other researchers say that the effective teacher is the only one who can play the main role in terms of student progress. All the factors (teacher, school context, classroom context and the community around the school) contribute or impact student's achievement. The effective school factors, which influence students, are: professional leadership, learning environment, high expectation, positive reinforcement, monitoring student's progress and parent-school co-operation (Ayres, Sawyer, \& Dinham, 2004; Bentley, 2000; and Owens, 1998)

Qualifications of teacher play important role in teaching but professional education or training is more important in teaching, because a trained teacher can teach better than an un-trained teacher. Generally, it is claimed that a trained teacher knows well how to teach effectively. Ruhela and Singh (1990), on the importance of teacher training writes that the schools could not succeed with out trained teachers, and specify the general areas of study in teacher education. Habiba (2004), also states that competency is knowledge, skill or characteristic we want students to acquire. If a trained teacher teaches the students, the performance of the student would be good because in the process of education, the teacher is considered the most crucial element. There is a direct relationship between the qualification of the teacher and the performance of the students besides other factors through effective teaching .

Teachers' subject area certification or authorization is one of the teacher qualifications most consistently and strongly associated with improved student achievement, especially in middle and high school mathematics (Betts et al. 2003, Cavalluzzo, 2004, Goldhaber \& Brewer, 2000). Carr (2006) also indicates that highly qualified teachers, or those with both full certification and demonstrated subject matter competency, are associated with increased elementary and middle school achievement in reading, science, and social studies as well as in mathematics.

Teachers' qualifications encompass teachers' scores on tests and examinations, their years of experience, the extent of their preparation in subject matter and in pedagogy, what qualifications they hold in 
their area of expertise, and their ongoing professional development. Student learning is taken simply as the gain scores students attain on achievement tests. Cochran-Smith (2001) went on to posit the relationship between teacher qualification and student learning as the percentage of variance in student scores accounted for by teacher qualifications when other variables are held constant or adjusted.

Teaching experience is the most consistent qualification that is linked to positive student achievement gains (Goe, 2007; Harris, 2007; Jepsen, 2005). Still, other studies have found no evidence for teacher experience effects or that the presence of effects varies by subject and grade level (Betts, Zau, \& Rice, 2003; Jepsen, 2005; Rivkin, Hanushek, \& kain, 2005). These conflicting studies may be due to findings that teachers gain in effectiveness in the first few years, but after a few years of teaching experience subsequent experience has no effect (Boyd et al., 2006; Harris, 2007).

The importance of experienced teachers in schools has been highlighted by many researchers (Akinleye, 2001; Ogundare 2001; Commeyras, 2003). Researchers have also given different opinions about teaching experience and students' learning outcomes in schools (Waiching, 1994; Ijaiya, 2000). Their arguments centred on the fact that experience improves teaching skills while pupils learn better at the hands of teachers who have taught them continuously over a period of years (Ijaiya, 2000).

The relationship between teachers experience and student achievement receives considerable attention in the empirical literature, with somewhat mixed results. Several researchers find that experience, especially during the first couple of years in the classroom, is positively associated with students' achievement in mathematics and reading at the elementary and middle school levels (Cavalluzzo, 2004; Hanushek et al., 2005; Rockof, 2004). Several other studies however, do not detect meaningful difference between more or less experienced teachers (Carr, 2006; Harbison and Hanushek, 1992). It is interesting to note that three of the four studies that find no significant relationships between teacher experience and student achievement do not focus on traditional public school. Both Gallagher and Carr examine charter schools, and Harbison and Hanashek's research looks at impoverished schools in rural Brazil.

Studies on the effect of teacher experience on student learning have found a positive relationship between teachers' effectiveness and their years of experience, but the relationship observed is not always a significant or an entirely linear one (Klitgaard \& Hall, 1974; Murnane \& Phillips, 1981). The evidence currently available suggests that while inexperienced teachers are less effective than more senior teachers, the benefits of experience level off after a few years (Rivkin, Hanushek, \& Kain, 2000).

The importance of experienced teachers in schools has been argued as being necessary for school effectiveness (Zaku, 1983). Several studies have found a positive effect of experience on teachers' effectiveness, specifically, "the learning by doing" effect is most obvious in the early years of teaching ( Rice, 2004; Bauer, 2005). Could this be the case in teaching elements of special education?

\section{Statement of the Problem}

This study attempted to assess teaching effectiveness as it relates to the teaching of Elements of Special Education Curriculum in NCE-awarding Institutions in Nigeria. It also investigated the extent to which teacher qualification and experience influence teaching effectiveness.

\section{Research Questions}

1. What is the status of the NCE-awarding institutions with respect to:

(a) lecturers' qualification

(b) lecturers' experience

2. How effective is the actual classroom teaching of Elements of Special Education Curriculum content in the NCE-awarding institutions in Nigeria?

\section{Hypotheses}

This study formulated and tested the following null hypotheses at $\infty=0.05$ level of significance.

1. There is no significant difference in the lecturers' teaching effectiveness in Elements of Special Education based on their educational qualification.

2. There is no significant difference in the lecturers' teaching effectiveness in Elements of Special Education based on their teaching experience.

\section{Methods and Materials}

\section{Research Design}

The study adopted the descriptive research design which was implemented expost facto. The study is also qualitative as it used the observational method to collect data on teaching effectiveness.

\section{Variables in the Study}

Three variables involved in the study are:

1. Lecturers' teaching effectiveness. 
2. Lecturers' qualification

3. Lecturers' experience

\section{Population}

The population for this study comprised all the two hundred and seventeen lecturers teaching Elements of Special Education Curriculum in these institutions.

\section{Instrument}

One instrument was used in this study. That is the Observational Schedule for Classroom Teaching of Elements of Special Education (OCTESE). This instrument was designed to observe lecturers during classroom teaching of aspect of Elements of Special Education Curriculum in selected NCE-Awarding institutions in Nigeria. It has 20 items on a 5-point rating scale. The items spanned from class atmosphere, instructional objectives, teaching techniques to evaluation and assignments. After peer/expert review, the instrument was used by a team of 4 observers who independently observed the same lecturer during classroom teaching at the same time. Their different ratings were then analysed for inter-rater reliability using Scott's $\pi$ and coefficient of 0.82 was obtained.

\section{Data Analysis}

Data collected were analysed using descriptive statistics i.e.frequency count, mean and standard deviation as well as one-way analysis of variance [ANOVA].

\section{Results}

Table 1: Qualification of the Lecturers

\begin{tabular}{|l|l|l|}
\hline Qualification & Frequency & Percent \\
\hline B.Ed. & 48 & 22.0 \\
B.Sc. + PGDE & 8 & 4.0 \\
M.Ed. & 86 & 40.0 \\
M.Sc./PGDE & 39 & 18.0 \\
Ph.D. without Education & 16 & 7.0 \\
Ph.D. with Education & 20 & 9.0 \\
Total & $\mathbf{2 1 7}$ & $\mathbf{1 0 0 . 0}$ \\
\hline
\end{tabular}

Table 1. shows that majority of the lecturers hold the M.Ed. (N=86; 39.65). In proportion, this group is followed by those with B.Ed. $(\mathrm{N}=48 ; 22.1 \%)$. Also, 39 lecturers $(18.0 \%)$ hold the M.Sc. with PGDE. Those in the minorities are B.Sc. + PGDE $(\mathrm{N}=8 ; 3.7 \%)$, Ph.D without Education $(\mathrm{N}=16 ; 7.4 \%)$ and Ph.D with Education $(\mathrm{N}=20 ; 9.2 \%)$. These various categories are qualified except that the B.Ed. and B.Sc. + PGDE could be considered low for teaching in tertiary institutions such as NCE-awarding institutions.

Table 2: Years of Experience of the Lecturers

\begin{tabular}{|l|l|l|}
\hline Experience (years) & Frequency & Percent \\
\hline Below 5 & 41 & 19.0 \\
$5-10$ & 44 & 20.0 \\
$11-15$ & 36 & 17.0 \\
$16+$ & 96 & 44.0 \\
Total & $\mathbf{2 1 7}$ & $\mathbf{1 0 0 . 0}$ \\
\hline
\end{tabular}

From Table 2, the highest proportion of lecturers have more than 16 years of teaching experience $(\mathrm{N}=96 ; 44.2 \%)$ while $41(18.9 \%)$ have below 5 years. This implies that the level of experience of the teachers is at the upper side of the continuum. Hence, their quality of teaching is expected to be effective.

\section{Answer to Research Questions}

Research Question 1: - How effective is the actual classroom teaching of Elements of Special Education curriculum content in the NCE-awarding institutions in Nigeria? 
Table 3: Classroom Situation for Teaching Elements of Special Education

\begin{tabular}{|c|c|c|c|c|c|c|c|c|}
\hline \multicolumn{9}{|c|}{$\mathrm{N}=20$} \\
\hline $\mathbf{S} / \mathbf{N}$ & LESSON FEATURES & 5 & 4 & 3 & 2 & 1 & Mean & $\begin{array}{l}\text { Std } \\
\text { De } \\
\text { v }\end{array}$ \\
\hline 1 & $\begin{array}{l}\text { Class Atmosphere } \\
\text { Conduciveness of the } \\
\text { classroom to the teaching of } \\
\text { special education }\end{array}$ & $\begin{array}{l}2 \\
(10.0)\end{array}$ & $\begin{array}{l}2 \\
(10.1)\end{array}$ & $\begin{array}{l}4 \\
(20.0)\end{array}$ & $\begin{array}{l}9 \\
(45.0)\end{array}$ & $\begin{array}{l}3 \\
(15.0)\end{array}$ & 2.55 & $\begin{array}{l}1.1 \\
9\end{array}$ \\
\hline 2 & $\begin{array}{l}\text { Arrangement of seats in line } \\
\text { with the strategy used, ease of } \\
\text { movement and proper } \\
\text { ventilation. }\end{array}$ & $\begin{array}{l}1 \\
(5.0)\end{array}$ & $\begin{array}{l}5 \\
(25.0)\end{array}$ & $\begin{array}{l}4 \\
(20.0)\end{array}$ & $\begin{array}{l}7 \\
(35.0)\end{array}$ & $\begin{array}{l}3 \\
(15.0)\end{array}$ & 2.70 & $\begin{array}{l}1.1 \\
7\end{array}$ \\
\hline
\end{tabular}

Table 3 shows that the classroom is fairly conducive (Mean $=2.55 ; \mathrm{SD}=1.17$ ) and the arrangement of seats is also fair (Mean = 2.70). These mean scores are about the average score considering the 5.00 maximum score obtainable. The 2.63 weighted average depicts a classroom atmosphere which is not good enough for the effective teaching of Elements of Special Education.

Table 4: Instructional Objectives in the Teaching of Elements of Special Education $\mathrm{N}=20$

\begin{tabular}{|c|c|c|c|c|c|c|c|c|}
\hline $\mathbf{S} / \mathbf{N}$ & $\begin{array}{l}\text { LESSON } \\
\text { FEATURES }\end{array}$ & 5 & 4 & 3 & 2 & 1 & Mean & $\begin{array}{l}\text { Std } \\
\text { Dev }\end{array}$ \\
\hline 1 & $\begin{array}{l}\text { Instructional } \\
\text { Objectives } \\
\text { Instructional } \\
\text { objectives well } \\
\text { communicated to } \\
\text { the students. }\end{array}$ & $\begin{array}{l}1 \\
(5.0)\end{array}$ & $\begin{array}{l}2 \\
(10.0)\end{array}$ & $\begin{array}{l}7 \\
(35.0)\end{array}$ & $\begin{array}{l}2 \\
(10.0)\end{array}$ & $\begin{array}{l}8 \\
(40.0)\end{array}$ & 2.30 & 1.26 \\
\hline 2 & $\begin{array}{l}\text { Extent to which } \\
\text { the content and } \\
\text { activities relate to } \\
\text { the objectives. }\end{array}$ & $\begin{array}{l}3 \\
(15.0)\end{array}$ & - & $\begin{array}{l}5 \\
(25.0)\end{array}$ & $\begin{array}{l}2 \\
(10.0)\end{array}$ & $\begin{array}{l}10 \\
(50.0)\end{array}$ & 2.20 & 1.47 \\
\hline 3 & $\begin{array}{l}\text { Coverage of } \\
\text { relevant aspects of } \\
\text { the topic based on } \\
\text { the objectives. }\end{array}$ & $\begin{array}{l}1 \\
(5.0)\end{array}$ & $\begin{array}{l}1 \\
(5.0)\end{array}$ & $\begin{array}{l}3 \\
(15.0)\end{array}$ & $\begin{array}{l}2 \\
(10.0)\end{array}$ & $\begin{array}{l}13 \\
(65.0)\end{array}$ & 1.75 & 1.20 \\
\hline
\end{tabular}

From Table 4, instructional objectives are not well communicated to students (Mean $=2.30$; SD = $1.26)$, content and activities are poorly related to the objectives (Mean $=2.20 ; \mathrm{SD}=1.47$ ) and relevant aspects of the topics based on the objectives are not covered (Mean $=1.75 ; \mathrm{SD}=1.20$ ). This situation is so poor as attested to by the low weighted average score of 2.08 out of 5.00. Hence, the use of instructional objectives in guiding the course of instruction is poor. 
Table 5: Techniques Used in Teaching Elements of Special Education

\begin{tabular}{|c|c|c|c|c|c|c|c|c|}
\hline \multicolumn{9}{|c|}{$\mathrm{N}=20$} \\
\hline $\mathbf{S} / \mathbf{N}$ & LESSON FEATURES & 5 & 4 & 3 & 2 & 1 & Mean & $\begin{array}{l}\text { Std } \\
\text { Dev }\end{array}$ \\
\hline 1 & $\begin{array}{l}\text { Teaching Techniques } \\
\text { Evidence of well planned and } \\
\text { internally consistent lesson. }\end{array}$ & $\begin{array}{l}2 \\
(10.0)\end{array}$ & $\begin{array}{l}2 \\
(10.0)\end{array}$ & $\begin{array}{l}5 \\
(25.0)\end{array}$ & $\begin{array}{l}3 \\
(15.0)\end{array}$ & $\begin{array}{l}8 \\
(40.0)\end{array}$ & 2.35 & 1.38 \\
\hline 2 & $\begin{array}{l}\text { Evidence of subject matter } \\
\text { mastery by the lecturer. }\end{array}$ & $\begin{array}{l}2 \\
(10.0)\end{array}$ & $\begin{array}{l}2 \\
(10.0)\end{array}$ & $\begin{array}{l}3 \\
(15.0)\end{array}$ & $\begin{array}{l}1 \\
(5.0)\end{array}$ & $\begin{array}{l}12 \\
(60.0)\end{array}$ & 2.05 & 1.46 \\
\hline 3 & $\begin{array}{l}\text { Variety and effectiveness of } \\
\text { procedures/strategies in line with } \\
\text { the principles of special education }\end{array}$ & - & $\begin{array}{l}2 \\
(10.0)\end{array}$ & $\begin{array}{l}8 \\
(40.0)\end{array}$ & $\begin{array}{l}2 \\
(10.0)\end{array}$ & $\begin{array}{l}88 \\
(40.0)\end{array}$ & 2.20 & 1.10 \\
\hline 4 & $\begin{array}{l}\text { Use of lecture/project/concept } \\
\text { mapping } \\
\text { Analogies/Topic study/ } \\
\text { Dramatization/Combination of } \\
\text { methods. }\end{array}$ & $\begin{array}{l}1 \\
(5.0)\end{array}$ & $\begin{array}{l}3 \\
(15.0)\end{array}$ & $\begin{array}{l}5 \\
(25.0)\end{array}$ & $\begin{array}{l}9 \\
(45.0)\end{array}$ & $\begin{array}{l}2 \\
(10.0)\end{array}$ & 2.60 & 1.04 \\
\hline 5 & $\begin{array}{l}\text { Skill in questioning (type, } \\
\text { frequency, relevance, distribution, } \\
\text { provocativeness, answerability). }\end{array}$ & $\begin{array}{l}9 \\
(45.0)\end{array}$ & - & - & $\begin{array}{l}4 \\
(20.0)\end{array}$ & $\begin{array}{l}7 \\
(35.0)\end{array}$ & 3.00 & 1.89 \\
\hline 6 & $\begin{array}{l}\text { Reflection of real-life challenges } \\
\text { and problems in classroom } \\
\text { teaching. }\end{array}$ & $\begin{array}{l}8 \\
(40.0)\end{array}$ & - & - & $\begin{array}{l}6 \\
(30.0)\end{array}$ & $\begin{array}{l}6 \\
(30.0)\end{array}$ & 2.90 & 1.80 \\
\hline 7 & $\begin{array}{l}\text { Potential of the lesson in } \\
\text { developing special skills and } \\
\text { positive attitudes in students. }\end{array}$ & $\begin{array}{l}9 \\
(45.0)\end{array}$ & - & - & $\begin{array}{l}6 \\
(30.0)\end{array}$ & $\begin{array}{l}5 \\
(25.0)\end{array}$ & 3.10 & 1.80 \\
\hline 8 & $\begin{array}{l}\text { Creation of avenues for solving } \\
\text { hypothetical problems. }\end{array}$ & $\begin{array}{l}3 \\
(15.0) \\
\end{array}$ & $\begin{array}{l}4 \\
(20.0) \\
\end{array}$ & & $\begin{array}{l}1 \\
(5.0)\end{array}$ & $\begin{array}{l}12 \\
(60.0) \\
\end{array}$ & 2.25 & 1.68 \\
\hline 9 & $\begin{array}{l}\text { Skill and language of } \\
\text { communication of the lecturer. }\end{array}$ & $\begin{array}{l}3 \\
(15.0)\end{array}$ & - & $\begin{array}{l}2 \\
(10.0)\end{array}$ & $\begin{array}{l}7 \\
(35.0)\end{array}$ & $\begin{array}{l}8 \\
(40.0)\end{array}$ & 2.15 & 1.38 \\
\hline 10 & $\begin{array}{l}\text { Provision and effectiveness of } \\
\text { relevant instructional materials } \\
\text { and equipment. }\end{array}$ & $\begin{array}{l}2 \\
(10.0)\end{array}$ & $\begin{array}{l}1 \\
(5.0)\end{array}$ & $\begin{array}{l}2 \\
(10.0)\end{array}$ & $\begin{array}{l}11 \\
(55.0)\end{array}$ & $\begin{array}{l}4 \\
(20.0)\end{array}$ & 2.30 & 1.17 \\
\hline 11 & $\begin{array}{l}\text { Involvement of students in class } \\
\text { activities and discussion. }\end{array}$ & $\begin{array}{l}3 \\
(15.0)\end{array}$ & - & $\begin{array}{l}1 \\
(5.0)\end{array}$ & $\begin{array}{l}9 \\
(45.0)\end{array}$ & $\begin{array}{l}7 \\
(35.0)\end{array}$ & 2.15 & 1.34 \\
\hline
\end{tabular}

Table 5 shows that three out of the eleven items yielded high mean scores ranging from 2.90 to 3.10 . These are items 5,6 and 7. To these ends, the lecturers' skills in questioning, reflection of real-life problems as well as the development of special skills and attitude in the students are demonstrated effectively. The use of effective instructional strategies is only fairly effective (Mean $=2.60 ; \mathrm{SD}=1.04$ ) while the remaining seven items yielded very low mean scores (means range between 2.06 and 2.35). The weighted average of 2.46 out of 5.00 suggests that the teaching techniques adopted are not effective. 
Table 6. Evaluation and Assignments in the Teaching of Elements of Special Education

\begin{tabular}{|c|c|c|c|c|c|c|c|c|}
\hline \multicolumn{9}{|c|}{$\mathrm{N}=20$} \\
\hline $\begin{array}{l}\mathbf{S} / \\
\mathbf{N}\end{array}$ & LESSON FEATURES & 5 & 4 & 3 & 2 & 1 & $\begin{array}{l}\text { Me } \\
\text { an }\end{array}$ & $\begin{array}{l}\text { Std } \\
\text { Dev }\end{array}$ \\
\hline 1 & $\begin{array}{l}\text { Evaluation } \\
\text { Assignments } \\
\text { Adequate evaluation of } \\
\text { attainment of instructional } \\
\text { objectives. }\end{array}$ & $\begin{array}{l}3 \\
(15.0 \\
)\end{array}$ & $\begin{array}{l}2 \\
(10.0\end{array}$ & $\begin{array}{l}2 \\
(10.0\end{array}$ & $\begin{array}{l}7 \\
(35.0\end{array}$ & $\begin{array}{l}6 \\
(30 .)\end{array}$ & 2.45 & 1.43 \\
\hline 2 & $\begin{array}{l}\text { Coverage of the six domains } \\
\text { viz knowledge } \\
\text { comprehension, application, } \\
\text { analysis, synthesis and } \\
\text { evaluation. }\end{array}$ & $\begin{array}{l}2 \\
(10.0\end{array}$ & $\begin{array}{l}2 \\
(10.0\end{array}$ & - & $\begin{array}{l}10 \\
(50.0 \\
)\end{array}$ & $\begin{array}{l}6 \\
(30.0)\end{array}$ & 2.20 & 1.28 \\
\hline 3 & $\begin{array}{l}\text { Relevant and adequate } \\
\text { assignments on the issue } \\
\text { taught. }\end{array}$ & $\begin{array}{l}8 \\
(40.0\end{array}$ & $\begin{array}{l}1 \\
(5.0)\end{array}$ & $\begin{array}{l}1 \\
(5.0)\end{array}$ & $\begin{array}{l}6 \\
(30.0\end{array}$ & $\begin{array}{l}4 \\
(20.0)\end{array}$ & 3.15 & 1.69 \\
\hline 4 & $\begin{array}{l}\text { Relevant and adequate } \\
\text { home/out of class project or } \\
\text { activities based on the } \\
\text { concepts taught. }\end{array}$ & $\begin{array}{l}4 \\
(20.0\end{array}$ & - & $\begin{array}{l}2 \\
(10.0\end{array}$ & $\begin{array}{l}4 \\
(20.0\end{array}$ & $\begin{array}{l}10 \\
(50.0)\end{array}$ & 2.20 & 1.57 \\
\hline
\end{tabular}

Table 6 shows that relevant assignments are adequately given to students on issues taught $($ Mean $=$ 3.15; $\mathrm{SD}=1.69)$. However, evaluation was not adequate (Mean = 2.45; $\mathrm{SD}=1.43$ ), the six domains are not covered in the evaluation done (Mean $=2.20 ; \mathrm{SD}=1.57$ ) and homework and projects are not used (Mean 2.20; $\mathrm{SD}=1.57$ ). Above all, the weighted average of 2.50 is just half of the maximum obtainable score of 5.00. This shows that evaluation and assignments in the Elements of Special Education are not well implemented.

Test of Hypotheses

Ho1: - There is no significant difference in the lecturers teaching effectiveness in Elements of Special Education based on their qualification.

Table 7: Descriptive Table for Teaching Effectiveness and Lecturers' Qualification

\begin{tabular}{|l|l|l|l|}
\hline Qualification & N & Mean & $\begin{array}{l}\text { Std. } \\
\text { Deviation }\end{array}$ \\
\hline B.Ed & 48 & 54.3542 & 14.7814 \\
B.Sc + PGDE & 8 & 61.2500 & 18.2502 \\
M.Sc & 86 & 52.0698 & 13.7480 \\
M.Sc + PGDE & 39 & 53.7436 & 14.5126 \\
Ph.D & 16 & 51.3500 & 16.7498 \\
Ph.D with Education & 20 & 55.1250 & 12.7534 \\
Total & $\mathbf{2 1 7}$ & $\mathbf{5 3 . 3 7 3 3}$ & $\mathbf{1 4 . 4 7 6 2}$ \\
\hline
\end{tabular}

Table 7 shows that lecturers with B.Sc. plus PGDE had the highest mean score in teaching effectiveness $($ Mean $=61.25$; $\mathrm{SD}=18.25)$. This is followed by lecturers with Ph.D. in Education $($ Mean $=55.13$; $\mathrm{SD}=12.75)$, those with B.Ed. $($ Mean $=54.35 ; \mathrm{SD}=14.78)$ and then those with M.Sc. plus PGDE (Mean 53.74; $\mathrm{SD}=14.51)$. Those with M.Sc. $($ Mean $=52.07 ; \mathrm{SD}=13.75)$ and Ph.D. without education $(\mathrm{Mean}=51.35 ; \mathrm{SD}=$ 16.75) fall on the lower part based on the magnitude of means scores.

Table 8: ANOVA (One-way) Table for Teaching Effectiveness by Qualification

\begin{tabular}{|l|l|l|l|l|l|}
\hline $\begin{array}{l}\text { Source of } \\
\text { Variance }\end{array}$ & $\begin{array}{l}\text { Sum of } \\
\text { Square }\end{array}$ & Df & $\begin{array}{l}\text { Mean } \\
\text { Square }\end{array}$ & F & Sig. \\
\hline $\begin{array}{l}\text { Between } \\
\text { Groups }\end{array}$ & 824.969 & 5 & 164.994 & .783 & $.563^{\text {n.s }}$ \\
$\begin{array}{l}\text { Within } \\
\text { Groups } \\
\text { Total }\end{array}$ & 44439.796 & 211 & 210.615 & & \\
\hline & 45264.765 & 216 & & & \\
\hline
\end{tabular}

n.s $=$ Not significant at $\mathrm{p}<.05$

Table 8 shows that the difference in the teaching effectiveness of lecturers based on their qualification is not significant $(\mathrm{F}=.783 ; \mathrm{p}<.05)$. Hence, Hypotheses 3 is not rejected. 
Ho 2: - There is no significant difference in the lecturers' teaching effectiveness in Elements of Special Education based on their teaching experience.

Table 9: Teaching Effectiveness of Lecturers with Different Levels of Experience

\begin{tabular}{|l|l|l|l|}
\hline Experience & N & Mean & $\begin{array}{l}\text { Std. } \\
\text { Deviation }\end{array}$ \\
\hline Blow 5 & 41 & 55.6585 & 15.0326 \\
$5-10$ & 44 & 53.4773 & 14.3535 \\
$11-15$ & 36 & 48.3889 & 14.0779 \\
$16+$ above & 96 & 54.2188 & 14.2358 \\
Total & $\mathbf{2 1 7}$ & $\mathbf{5 3 . 3 7 3 3}$ & $\mathbf{1 4 . 4 7 6 2}$ \\
\hline
\end{tabular}

Table 9 shows that lecturers with less than 5 years teaching experience had the highest mean score $($ Mean $=55.6 ; \mathrm{SD}=15.03)$ in teaching effectiveness. This group is followed by those with $5-10$ years $($ Mean $=$ 53.48; $\mathrm{SD}=14.35$ ). The lecturers with 11-15 years had the lowest mean score (Mean 48.39; $\mathrm{SD}=14.08$ ).

Table 10: ANOVA (One-way) Table for Teaching Effectiveness by Years of Experience of Lecturers

\begin{tabular}{|c|c|c|c|c|c|}
\hline $\begin{array}{ll}\text { Source } & \text { of } \\
\text { Variance }\end{array}$ & $\begin{array}{l}\text { Sum of } \\
\text { Square }\end{array}$ & Df & $\begin{array}{l}\text { Mean } \\
\text { Square }\end{array}$ & $\mathbf{F}$ & Sig. \\
\hline $\begin{array}{l}\text { Between } \\
\text { Groups } \\
\text { Within } \\
\text { Groups } \\
\text { Total }\end{array}$ & $\begin{array}{l}1177.606 \\
44.87 .159 \\
45264.765\end{array}$ & $\begin{array}{l}3 \\
213 \\
216\end{array}$ & $\begin{array}{l}392.535 \\
206.982\end{array}$ & 1.896 & $.131^{\mathrm{n} . \mathrm{s}}$ \\
\hline
\end{tabular}

n.s $=$ Not significant at $\mathrm{p}<.05$

From Table 10, the difference in the teaching effectiveness of the lecturers as obtained in Table 4.25 is not significant $(\mathrm{F}=1.896 ; \mathrm{p}<.05)$. Hence, hypothesis 4 is not rejected.

\section{Summary of findings}

1. Qualification and experience of lecturers of Elements of Special Education do not significantly affect their teaching effectiveness. Those with B.Sc. + PGDE and those with below 5 years experience teach more effectively than the other classes of lecturers.

2. The classroom teaching of the course is not effective enough considering class atmosphere, use of instructional objectives, teaching techniques, evaluation and assignments.

3. Lecturers of Elements of Special Education predominantly use the lecture method while they occasionally adopt discussion and demonstration methods.

\section{Discussion}

It was also found that the lecturers were mostly academically qualified. This present finding on the qualification of the personnel who teach in these institutions sampled was contrary to the finding of Boe and Cook (2006) as well as Billingsloy, Fall and Williams (2006) which revealed high percentage of uncertified educators staffing special education institutions in the USA. This was a development which was cheery in spite of the fact that the academic qualifications of many of them is not directly in special education. Indeed, some of them studied such education courses as: Education Psychology, Guidance and Counselling, Educational Management and the likes. These lecturers were appointed and assigned the course with the unjustifiable assumption that they could teach special education effectively. This could lead to the situation where topics which are technical or beyond the level of the teacher would be left untaught with attendant poor students' performance in the course. This present finding corroborates the reports of Trait and Purdie (2000), Cook (2001) and Praisner (2003) who all berated poor qualification of personnel in Special Education

However, this phenomenon should be looked into by the Federal Government of Nigeria because of the importance attached to using teachers who are qualified to teach learners (Betta, Zau and Rice, 2003, Hannshek et al. 2002). Further, allowing this scenario outline by the present study to continue has the capacity of jeopardizing the government's noble intentions for establishing these institutions. This is because, it has been reiterated by researchers (Rockoff 2004 \& Goe, 2007) that the logical starting point for any policy to address the achievement of students with special needs is the quality of teachers instructing them.

Facilities and specialized equipment are required in teaching Element of Special Education. Indeed, pre-science teachers need to be trained in their use or at least have a first hand interactive experience with the 
materials. This practice may not augur well with the experiences the teachers in training are exposed to and may affect their classroom behavior during practice. This is so viewed because research has shown that relationship exists between types of training special education teachers and their classroom practices (Algozzine, Morsink and Nougaret 1988 and Nougaret, Scruggs and Nastropieri, 2005). This result also runs contrary to the objectives of setting up teacher education institutions in Nigeria. Graduates of Nigeria Certificate in Education (NCE) who are not exposed to the skills of identification, specialized equipment like Braille machines and so on would negate the whole essence of the programme especially now that basic education in Nigeria is free and compulsory for all Nigerian children.

Findings further revealed that the classroom teaching is not effective in every ramification ranging from class atmosphere, use of instructional objectives, teaching techniques, evaluation and assignments. This could be traced to the problems of large class size, workload of the few lecturers available, lack of facilities and equipment, high cost of these specialized equipments, lack of funds, society's negative attitude and students' apathy. Ineffective classroom teaching found in this study is in tandem with findings of Braun (2005), McCaffery et al. (2004) and Sanders (2000) who traced poor student performance to teachers' poor effectiveness in teaching.

\section{Conclusion and Recommendations}

The study x-rayed the influence of qualification and experience on effective teaching in element of special education in NCE-awarding institutions in Nigeria. From the findings, it was observed that qualifications of teachers do not significantly affect their teaching effectiveness. However, classroom teaching is not effective enough, and lecturers make frequent use of lecture method and seldom use of discussion and demonstration methods. Equally, the results of this study have shown that the classroom teaching of Elements of Special Education is not conducive enough and teachers handling the programme are largely not qualified in terms of professional skills and are less organised.

In view of the findings of this study, the following recommendations are made:

- Government should encourage teacher education in the area of special education in Nigerian universities

- In-service training should be provided/organised for teachers of Elements of Special Education in NCEAwarding institutions in Nigeria,

- Effective methods of teaching Elements of Special Education should be adopted by teachers in NCEAwarding institutions in Nigeria,

- A better classroom design and organisation should be put in place for effective teaching of Elements of Special Education in the institutions.

[1]. Aggarwal, J. C. 1997. Theory and Principles of Education, (10th revised Ed.). New Delhi: Vikas Publishing House, PVT. Ltd., pg. 4,10 .

[2]. Akinleye, G. A. 2001. "Early childhood education: Guide for parents and teachers" UNAD J. Educ., 2 (1) October; .45.

[3]. Algozzine, B., Morsink, C. V., \& Algozzine, K. M. 1988. What's Happening in Self-contained Special Education Classrooms? Exceptional Children, 55(3), 259 - 65.

[4]. Ayres, P., Sawyer, W., \& Dinham, S. 2004. Effective Teaching in Context of a Grade 12 High Stakes External Examination in New South Wales, Australia. British Education Research Journal, 30(1), 141-165.

[5]. Bauer, B. S. (2005) Teaching english in Africa: Volunteer opportunities abound for young and old Retrieved (2005) from http:/www.peacecorps.gov/index.cfm

[6]. Bentley, J. 2000. School Effectiveness, School Improvement and Assuring Quality. In S. Dinham \& C. Scott (Eds.), Teaching in Context (pp. 154-169). Victoria: The Australian Council for Education Research.

[7]. $\quad$ Betts, J. R., Andrew, C. Z., and Lorien A. R., 2003. "Determinants of Student Achievement: New Evidence from San Diego." San Diego, CA: Public Policy Institute of California.

[8]. Billingsley, B., Anna-Maria, F., \& Thomas, O. W. 2006. Who is Teaching Students with Emotional Disorders? A Profile and Comparison to Other Special Educators. Behavioral Disorders, 31(1), 252-64.

[9]. Boe, E. E., \& Lynne, H. C. 2006. "The Chronic and Increasing Shortage of Fully Certified Teachers in Special and General Education." Exceptional Children, 72(4), 443-60.

[10]. Boyd, Donald, Pamela Grossman, Hamilton Lankford, Susanna Loeb, and James Wyckoff. 2006. "How Changes in Entry Requirements Alter the Teacher Workforce and Affect Student Achievement." Education Finance and Policy, 1(2): $176-216$.

[11]. Braun, H. J. 2005. Using Student Progress to Evaluate Teachers: A Primer on Value-Added Models. Princeton, NJ: Educational Testing Service. Available online at: http://www.ets. org/research/pic. Retrieved February 28, 2008.

[12]. Carr, M. 2006. The determinants of student achievement in Ohio's Public Schools (Policy Report). Colwnbus, OH: Buckeye Institute for Public Policy Solutions. http://www.buckeyeinstitute.org/docs/policy Report-Deterimants-of-Students-Achievementin-ohio.pdf. Retrieved February 28, 2008.

[13]. Cavalluzzo, L.C. 2004. Is National Board Certification an Effective Signal of Teacher Ouality? (Report No. IPR 11204). Alexandria, VA: The CAN Corporation. http://www.cna.org/documents/Cavalluzzo Retrieved February 28, 2008.

[14]. Cochran-Smith, M. 2001. The Outcomes Question in Teacher Education. Teaching and Teacher Education, 17,527 - 546.

[15]. Commeyras, M. (2003) "Promoting a culture of reading" The Comet Thursday, February 13, 32.

[16]. Cook, B. 2001. A Comparison of Teachers' Attitudes toward Their Included Students with Mild and Severe Disabilities. The Journal of Special Education, 34(4), 203-213.

[17]. Eleri, N.O. E. 2012. Evaluation of Implementation of Elements of Special Education Curriculum in NCE-Awarding Institutions 
in Nigeria. Unpublished Ph.D. Thesis University of Ibadan, Ibadan.

[18]. Federal Republic of Nigeria, 2004. National policy on education. Lagos: NERDC Press.

[19]. Goe, L. 2007. The Link between teacher quality and student outcomes: A research synthesis. Washington, DC: National Comprehensive Center for Teacher Quality. Retrieved February 27, 2008, from http://www.ncctq.org/publications/linkBetweenTQandStudentOutcomes.pdf

[20]. Goldhaber, D. D., \& Brewer, D. J. 2000. Does Teacher Certification Matter? High School Teacher Certification Status and Student Achievement. Educational Evaluation and Policy Analysis, 22(2), 129-145.

[21]. Habiba, U. 2004. An Impact of Professional Background and Competencies of Teachers of Elementary Colleges on the Achievement of Their Students, Unpublished Thesis submitted for the Degree of M.Phil Education, Department of Education, Multan: Bahauddin Zakariya University.

[22]. Hanushek, E. A., Kain, J. F., \& Rivkin, S. G. 2002. "Inferring Program Effects for Specialized Populations: Does Special Education Raise Achievement for Students with Disabilities? Review of Economics and Statistics, 84(4), 584-99.

[23]. Hanushek, E. A., Kain, J. F., O’ Brien, D. M., \& Rivkin, S. G. 2005. The Market for Teacher Quality (Working Paper No. 11156). Cambridge, MA: National Bureau of Economic Research.

[24]. Harbison, R.W., \& Hanushek, E. A. 1992. Educational Performance of the Poor: Lessons from Rural Northeast Brazil. New York: Oxford University Press.

[25]. Harris, D. N. 2007. Teacher training, teacher quality, and student achievement. Retrieved

[26]. February 20, 2008, from http://teacherqualityresearch.org/teacher_training.pdf

[27]. Harris, D. N., \& Sass, T. R. 2008. Teacher Training, Teacher Quality and Student Achievement. CALDER Working Paper 3. Washington, D.C.: The Urban Institute.

[28]. Ijaiya, N. Y. (2000) "Failing schools' and national development: Time for reappraisal of school effectiveness in Nigeria" Niger. J. Educ. Res. Eval. (2): 2; 42.

[29]. Jepsen, C. (2005). Teacher characteristics and student achievement: Evidence from teacher surveys. Journal of Urban Economics, 57(2), 302-319.

[30]. Kavale, K. A. 2005. Effective Intervention for Students with Specific Learning Disabilities: The Nature of Special Education: Learning Disabilities. A Multidisciplinary Journal, 13(4), 127 - 138.

[31]. Klitgaard, R. H., \& Hall, G. R. 1974. Are There Unusually Effective Schools? Journal of Human Resources, $10(3)$, 40 - 106.

[32]. McCaffrey, D. F., Lockwood, J. R., Koreetz, D., Louis, T. A., \& Hamilton, L. 2004. Models for Value-added Modelling of Teacher Effects. Journal of Educational and Behavioural Statistics, 29(1), 67-101.

[33]. Murnane, R. J., \& Phillips, B. 1981. Learning by Doing, Vintage, and Selection: Three Pieces of the Puzzle Relating Teaching Experience and Teaching Performance. Economics of Education Review, 1(4), 453-465.

[34]. Nougaret, Andre, Thomas Scruggs, and Margo Mastropieri. 2005. Does Teacher Education Produce Better Special Education Teachers? Exceptional Children, 71(3), 217-229.

[35]. Ogundare, S. F. (2001) "Purposes and problems of recess in Nigerian primary schools" UNAD J. Educ. 2 (1) October 2001; 4 8 .

[36]. Owens, R. 1998. Organizational Behaviour in Education (6 ${ }^{\text {th }}$ Ed.). Needham Height, MA: Allyn and Bacon.

[37]. Praisner, C. 2003. Attitudes of Elementary School Principals toward the Inclusion of Students with Disabilities. Council for Exceptional Children, 69(2), 135-145.

[38]. Pugach, M. C. (2005). Research on Preparing Teachers to Work with Students with Disabilities. In M. Cochran-Smith \& K. M. Zeichner (Eds.). Studying Teacher Education: The Report of the AERA Panel on Research on Teacher Education (pp. 549-590). Mahwah, N. J.: Erlbaum.

[39]. Rice, J. K. (2004) Teacher Quality understanding the effectiveness of teacherattributes The Economic Policy Institute EPI Books August, Retrieved (2004) from http://www.epinet.org/content.cfm.economist.

[40]. Rivkin, S. G., Hanushek, E. A., \& Kain, J. F. 2000. Teachers, Schools and Academic Achievement (working paper 6691, revised). Cambridge, MA: National Bureau of Economic Research.

[41]. Rivkin, S.G., Hanushek,E. A. and Kain, J. F. 2005. "Teachers, Schools and Academic Achievement." Econometrica, 73(2): 417 -458 .

[42]. Rockoff, J. E. 2004. The Impact of Individual Teachers on Student Achievement: Evidence from Panel Data. American Economic Review, 94(2), 247 - 252.

[43]. Ruhela, S. P., \& Singh, R. P. 1990. Trends in Modern Indian Education. New Delhi: Uppal Publishing House. pg. 395.

[44]. Sanders, W. L. 2000. Value-added Assessment from Student Achievement Data: Opportunities and Hurdles. Journal of Personnel Evaluation in Education, 14(4), 329-339.

[45]. Sial, Z. A. 2005. Identification of Indicators for the Effectiveness of Teachers at University Level. An unpublished Dissertation M.Phil Education, Multan: Department of Education, Bahauddin Zakariya University.

[46]. Tait, K., \& Purdie, N. 2000. Attitudes toward Disability: Teacher Education for Inclusive Environments in an Australian University. International Journal of Disability, Development and Education, 47(1), 25-38.

[47]. Tania, U. 2004. Evaluation of Teachers Training Programme under Science Project in Vehari City, Unpublished Thesis submitted for the Degree of $\quad$ M. A. Education, Department of Education, Multan: Bahauddin Zakariya, University.

[48]. Waiching, E. M. (1994) "Reflecting on reflections: A case study of experienced and inexperienced ESL teachers" System 22 (1) Pergamon Elsevier Science Ltd. 93.

[49]. Zaku, A.B.D. (1983) "The relationship between some school factors and students' performance in chemistry in the Gongola State of Nigeria" Unpublished PhD Thesis, University of Hull, United Kingdom. $86-88$ 